\section{Entrevista com Teresa Poester ${ }^{1}$}

\section{Teresa Poester}

Artista e professora de desenho no Instituto de Artes da UFRGS em Porto Alegre. Expôs em vários países incluindo individuais no Brasil, Argentina, Espanha, França e Bélgica. De 1979 a 1986 dedica-se ao movimento de Arte Postal e trabalha como professora, artista gráfica, cenógrafa e ilustradora. Entre 1986 e 1989 estuda pintura em Madri. Entre 1998 e 2002 habita na França para realizar doutorado na Universidade de Paris 1, Panthéon-Sorbonne. Volta a viver na França em 2006. Em 2009, retoma suas atividades como professora no IA-UFRGS criando o Atelier D43, grupo que explora o desenho combinado a outras linguagens artísticas. Atualmente, entre a França e o Brasil, trabalha em Eragny-sur-Epte e Porto Alegre.

Fonte: http://www.teresapoester.com.br

Leandro Serpa [L. S.]: A professora comenta em seu site que iniciou pelo desenho e que após sua passagem pela Espanha, a figuração narrativa dá lugar à paisagem. Gostaria que comentasse esta passagem.

Teresa Poester [T.P.]: Na verdade, trabalhei com muitas coisas diferentes, fui também estudante e professora de matemática, trabalhei até como bancária, e depois como artista gráfica, cenógrafa para teatro e cinema, e me dedicando ao movimento de Arte Postal. Mas, além da criação artística, ser professora de artes passou a ser a atividade mais constante. E é até hoje meu meio de sobrevivência. Sempre gostei disso. Não pretendia ganhar a vida como artista. E acho que por ser professora, há uma certa linearidade em minha trajetória de trabalho. Ou seja, mudanças são permanentes, mas sem grandes saltos. o trabalho desdobra-se nele e dele mesmo. Só quando fui estudar pintura na Espanha, já com 30 anos, depois de ter concluído o Instituto de Artes (havia vivido no Rio de Janeiro e acabei tarde) houve uma transformação mais radical. Era meu sonho viver na Europa, não queria ir como turista. Consegui uma bolsa do governo espanhol e foi, para mim, um período de mudanças fundamentais. Embora eu tenha 


\section{(X) Rvyssta \\ A APOTHEKE}

frequentado a Universidad Computense de Madrid, os artistas que me marcaram mais não foram os que conheci na Universidade. Tive um aprendizado mais direto através de experiências com pintores, principalmente espanhóis, e artistas também de outras áreas, num programa chamado 'taller da art actual', no Círculo de Bellas Artes de Madrid. Funcionava num espaço bem maior do que este (referenciando o Ateliê de Pintura da UDESC), onde se ficava o dia todo trabalhando. Os jovens artistas enviavam - portfólio e os 15 que tinham a sorte de serem selecionados pelo responsável do ateliê, trabalhavam durante um mês sob sua supervisão. Ficávamos todo o tempo para aproveitar ao máximo. Durante um mês de manhã, tarde e noite trabalhando. Fiz grandes amigos lá que conservo até hoje. Artistas de vários países eram convidados a orientar esses 'talleres'; uns, mais famosos, não ficavam o dia todo, mas vinham frequentemente e observavam os trabalhos de todos. Havia o momento da 'charla', como eles chamam, onde sentávamos para conversar. Nesse período, saí daquela coisa mais figurativa e caricatural, não era bem caricatura. Durante certo tempo, ainda no Brasil, as figuras intencionalmente estereotipadas tinham uma influência tragicômica de um certo realismo mágico, mas sempre com a preocupação de fazer um trabalho brasileiro. Queria mostrar a mistura entre o popular e o erudito que existia no Brasil. Trabalhava com crianças nessa época, o trabalho também absorvia essa coisa do cômico e do trágico dos contos de fadas, além das tradições populares. Alguns fiz inclusive aqui em Santa Catarina com figuras vestidas para a Festa do Divino, elementos da religiosidade, uma 'mistureba' que, na Espanha, foi dando lugar a símbolos locais para desaparecer gradativamente. Eu queria muito trabalhar com pintura justamente porque minha pintura era 


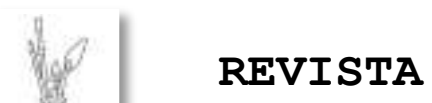 \\ A APOTHEKE}

muito ruim e uma maneira mais abstrata porque não sabia fazer. Queria aprender a pintar. Achava que aquilo não era pintura. Ainda em papel e com camadas de tinta magras, era um desenho pintado. Em Madri, comecei a trabalhar com encáustica, aí sim na Universidade. Na encáustica e com o maçarico não havia como controlar o contorno e a figura começou a se fundir com o fundo. Como falou uma amiga na época, era como se o trabalho estivesse chacoalhado num liquidificador. A partir daí, se tornou mais abstrato e dessas manchas começaram a surgir paisagens. Nas casas e apartamentos em Madri tem sempre sacadas que eles chamam balcões. Os desenhos desses balcões serviam depois de esqueleto construtivo, davam o ritmo e a estrutura que permitia a liberdade das paisagens no fundo. Essa relação entre paisagem e a abstração presente no meu trabalho sempre me interessou, teoricamente também. Os primeiros pintores abstratos foram paisagistas. Escrevi muito sobre isso tanto no Mestrado quanto no Doutorado. Agora, respondendo à pergunta, a figura saiu quando fui morar fora (na Espanha) e penso que a paisagem tem a ver com o fato de se estar longe. Isso pode ter influído também. Os teóricos sempre falam que a paisagem é uma construção cuja condição de afastamento é essencial. E é uma construção da memória. Nasci numa cidade pequena com uma paisagem provinciana. Fui para Porto Alegre ainda criança. Então, parece que aquilo volta quando se está longe outra vez, e ressurge a nostalgia da paisagem de origem.

L.S.: Observei o vídeo de Ana Luiza Azevedo e o momento em que você fala sobre o enquadramento da paisagem através da janela. Você discute isto também na série Jardins e diz que a janela seria uma forma de enquadrar a paisagem, de traçar paralelos entre pintura e paisagem? 


\section{\)}

T.P.: A partir do momento em que começo a trabalhar com paisagem, de certa forma tudo o que faço tem relação com isso, só que vai mudando, inclusive de técnica. Os primeiros trabalhos que chamei paisagem não eram bem figurativos. Já eram em tinta acrílica sobre tela e não havia mais o contorno do desenho, eu já considerava pintura. Quando fiz o Mestrado começou a haver uma segmentação do quadro em várias partes e comecei a relacionar essas partes. Esses fragmentos formavam uma geometria que chamei de janelas, mas não eram janelas no sentido literal, representativas. Eram enquadramentos abertos a diferentes cenários que se uniam através de associações formais dentro do espaço único do quadro. Como quadros dentro do quadro.

L.S.: Seria esta a série exposta no Torreão?

T.P.: Exato. Mas este foi um trabalho específico para o local e tinha como finalidade ser interativo. Com o enquadramento da paisagem que dá origem às janelas foi havendo segmentações ortogonais. O quadro já não era tão fortemente gestual, havia elementos quase geométricos. Eu trabalhava às vezes com fita adesiva, com linhas retas. O exagero dessa segmentação dá origem à outra série que chamei de 'grades'. Essas redes ortogonais das grades possibilitam uma volta ao desenho. E quando eu estava num processo obsessivo dessas grades, que eram trabalhadas como num gesto de esgrima, me tornei meio fechada neste processo. Fiz alguns desenhos de observação dos jardins de minha casa em Eragny sur Epte. Surgiram formas mais orgânicas da natureza arredondada do verão na Normandia. Este período chamei de Jardins de Eragny. Nesse momento, começo a trabalhar texturas. Se olhares meus textos (alguns estão no site) há alguns sobre paisagem e sobre a janela 


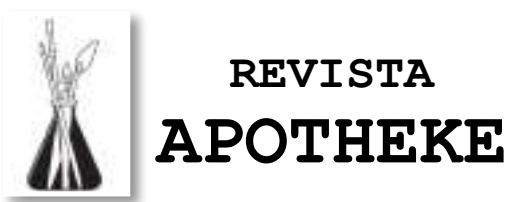

como enquadramento da paisagem dentro da História da Arte. Por que surgiu a janela, surgiu junto com a paisagem no Renascimento? Talvez para enquadrar a paisagem que não existia ainda na Idade Média. Com o humanismo renascentista surgiu a necessidade de situar o homem no seu espaço, no aqui e agora. Antes a figura humana era quase um boneco estereotipado. A figura se torna uma personagem real ocupando um espaço real. Mas ainda não sabiam resolver direito isso dentro da perspectiva linear que não se aplica à paisagem como a perspectiva aérea. E alguns pintores passaram a utilizar o recurso da janela como estratégia para situar a personagem no quadro. A janela era também usada para criar um espaço e uma narrativa paralela à da cena principal. Procurei abordar essas coisas na Tese de Doutorado que fiz lá na França cujo título é: 'Fronteiras da Paisagem: Janelas e Grades'.

L.S.: Observo que sua obra atual parte da paisagem na pintura, com a cor. No Mestrado você discute a paisagem e no Doutorado você tem contato com os jardins franceses que é uma forma que podemos chamar de tratar a paisagem. Seria isto?

T.P.: Quando fui para a França estava nesse período das grades e voltando a me apaixonar pelo desenho que tinha começado lá atrás com aquelas figuras humanas estereotipadas. Com as grades era um desenho completamente diferente. Estava iniciando a Tese e não sabia bem de onde partir. Pensei nessas pinturas de paisagem e de janela, a fatura da pintura e da cor, como disseste, como ponto de partida. Mas qual era minha exatamente minha pergunta? Pois, para fazer uma Tese tem que haver uma pergunta, não é? E me dei conta de que a minha era muito simples: Por que eu ainda desenhava e pintava? Só isso. Partir de uma coisa 


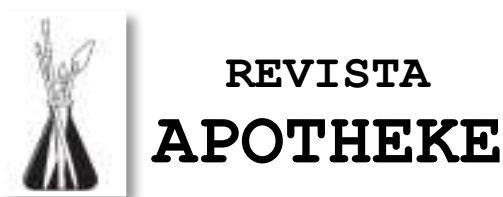

simples que fosse genuína, descobrir porque estava ainda fazendo isso quando poderia, como muitos de meus companheiros, conquistar o espaço tridimensional ou trabalhar em outras linguagens. Nesse momento, percebi que não interessava mais a representação ou passar uma ideia, como talvez lá no início e tal. O importante era mostrar o gesto através da mão que treme, que traduz o sentimento e o pensamento. Mostrar o desenho como escritura do corpo, um gesto em vias de desaparecimento. Aos poucos entendi que, nesse momento, a cor já não me interessava. O gesto seria mais visível em preto e branco. Tampouco me interessava a mancha. Fui dispensando tudo o que não era essencial. Ao final, concluí que a linha é capaz de registrar o movimento mais do que a mancha ou a cor. Em geometria, a linha é o ponto que se desloca. Há a noção de deslocamento na gênese do desenho, pois desenho é linha. E a ideia de movimento é a base do gesto. Podemos pensar que fui aproximando o olhar sobre a paisagem como num zoom, afunilando o enquadramento. Não me interessava a paisagem em si, mas a gestualidade que proporciona, a estrutura da natureza que ensina diferentes texturas, possibilidades de abstração orgânicas ou geométricas. Tens razão quando falas do lugar, porque tenho um vínculo enorme com esse lugar na França. Vou agora mesmo passar dois meses lá. É uma paisagem de campo onde tenho um ateliê. É um local com uma natureza exuberante e orgânica no verão, e fria no inverno, com seus galhos secos contra a neve. Cenários completamente diferentes. No inverno não tem cor e é tudo geométrico, isso me interessa. Se olhares aqui, (mostra um catálogo) verás que tem uma passagem. Isso foi uma exposição recente, mas não é só desenho, é gravura misturada com outras linguagens. Nessa montagem de $12 \mathrm{~m}$ de largura, inverno e verão, geométrico e orgânico, se misturam na medida em que o observador se desloca para ver 


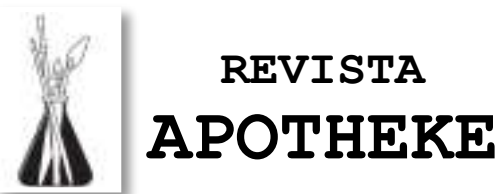

a instalação. Esse desenho vem da reflexão que a natureza proporciona. Por que é preto e branco? Por que é azul ou verde? Talvez não pareça, mas tudo é extremamente pensado.

L.S.: Você poderia comentar se há alguma relação entre o olho que apreende e a mão que realiza na sua relação com a paisagem?

T.P.: Eu não fecho o olho, não vejo nada, não imagino uma coisa e tento fazer o que imaginei. E, hoje em dia, poucas vezes desenho de observação. As vezes até desenho, mas não tenho mais esse hábito. Esta coisa mais orgânica surgiu em um momento em que esgotou a série das grades. E aí foi a observação que proporcionou a mudança, mas logo comecei outra coisa. E a coisa dá no confronto com o suporte, papel ou tela. É o fazer que gera o processo do desenho. E quando estou repetindo um gesto, me incomodo. Trabalho há quase quarenta anos, certos automatismos reconheço bem. Muitas vezes estou ali no automático, entende, é fácil. Então preciso criar estratégias para burlar esse automatismo, por exemplo, trabalhar com extensor, trabalhar com a mão esquerda, com gravura, como é o caso agora nessa exposição onde misturei uma série de procedimentos a partir de uma série de gravuras, usei muito o computador e só então vim com gesto do desenho. Criei uma nova técnica que nada mais é do que uma estratégia para obter uma gestualidade que me surpreenda dentro do que faço. Essa exposição só aconteceu porque criei esse procedimento. Esses trabalhos foram idealizados especialmente para o grande espaço da Galeria Bolsa de Arte de Porto Alegre. O catálogo Anagramas dá uma ideia da escala dos trabalhos no espaço expositivo. Trabalhei durante quatro meses nesse projeto. Já havia produzido as gravuras na Fundação Iberê Camargo no ano passado e resolvi fotografá-las e trabalhá-las no 


\section{\)}

computador como parte de minha pesquisa de fusão das linguagens. Precisei ser muito organizada nesse processo. Somente depois na última camada interferi diretamente com desenho sobre a impressão em grandes dimensões das gravuras anteriormente fotografadas. O processo começou com o desenho na chapa e foi concluída com desenho sobre o papel impresso. A cada vez que estou no computador meu olho seleciona, desenha. Uma vez os impressos ampliados, uma parede tão grande no ateliê, desenhava por partes. Tinha o conjunto no computador no pensamento. Não sou purista para achar que desenho é só lápis e papel, o grupo Atelier D43, que existe há 5 anos, tem site e página no Facebook, trabalha o desenho misturado ao vídeo e outras linguagens contemporâneas. Seguidamente, jovens artistas de Santa Catarina vêm à Porto Alegre participar de nossas atividades.

L.S.: Na entrevista que realizei com Vergara, o artista fala sobre o desconhecimento acerca dos processos artísticos contemporâneos e usa a palavra 'eloquência' para se referir à obra 'pronta' para ser exposta. São questões que a professora colocou aqui. Poderia falar mais sobre este assunto?

T.P.: Não é nada correto, mas quando falamos de eloquência muitas vezes vem a palavra 'grandiloquência' quase como um sinônimo, não é? Há um texto meu 'Sobre o Desenho' que fala da diferença entre desenho e pintura e fala nessa ideia. Em síntese, diz que o desenho não tem a grandiloquência da pintura na História da Arte porque nunca foi uma linguagem em si, isso é muito recente. No século XVII, já havia colecionadores de desenho, mas era uma coisa muito rara, um capricho de poucos. E não eram para colocar na parede, mas para ser visto em mesas, na horizontal, de forma íntima, 


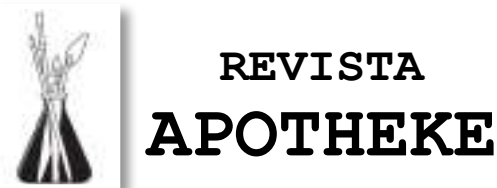

reservada. O desenho conservou durante muito tempo a característica de algo privado. E talvez esse seja seu maior atrativo. Mas se seu aspecto confidencial me interessa por um lado, por outro meu trabalho procura conferir ao desenho uma certa eloquência ou grandiloquência no sentido do grande formato e de abolir o contorno, o que aproxima o trabalho da pintura. São aparentes contradições que nem sempre nos damos conta. Mas penso que através das contradições, o pensamento evolui.

L.S.: Gostaria que falasse sobre o desdobramento que ocorre em seu processo criativo que se caracteriza pela mudança de suporte e uso de mídias diversas.

T.P.: É! A palavra é esta, desdobramento! Agora produzi uma série com gravura, por exemplo. É um desdobramento natural, um processo que vai acontecendo, às vezes, ao longo de muitos anos. Esse trabalho com a natureza, com o tema dos jardins, que parte da janela, do enquadramento, me levou a fotografar neste lugar da campanha francesa há quase 20 anos. Não fotografava a paisagem, as pessoas, até fotografava para meu arquivo pessoal, mas para arquivo de trabalho, fotografava o chão, o pedaço de árvore. Ia relacionando texturas da natureza e de desenhos. Alguns colegas do Instituto de Arte que foram visitar meu ateliê, como Alfredo Nicolaievski, perceberam que a paisagem de Eragny tinha tudo a ver com meus desenhos. Lembro que na chegada disse: 'Teresa, da janela do trem eu via teus desenhos passando'. Era dezembro e os galhos negros pontiagudos e secos se destacavam contra um fundo de neve. Logo depois, fiz uma exposição em um Castelo em Gisors onde havia janelas compridas daquelas medievais, sabe? Alguns desenhos ficavam ao lado dessas janelas e pensei: 'Tem tudo a ver realmente, a paisagem de dentro e de fora'. Nesse 


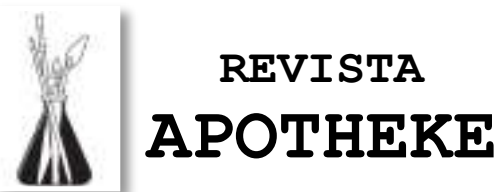

momento, comecei a fotografar de forma mais sistemática. Mas nunca desenhei a partir de fotos, ao contrário, fotografava pensando nos desenhos que já haviam sido feitos. Queria entender a relação entre uma coisa e outra. Não sabia no que isso iria resultar. Acabou que selecionei umas duas mil imagens e comecei a associá-las criando apresentações no Power Point. Fui experimentando sem expectativas e mostrei para um pianista francês, com quem já havia feito algumas coisas, é um músico maravilhoso. Ele gostou muito e me sugeriu criar um vídeo para contracenar com um concerto seu em uma igreja com uma composição de Morton Feldmann (o grande compositor americano do grupo de John Cage responsável pela fusão da música com outras formas de arte). Selecionei por volta de 900 imagens fixas e editei o vídeo de 78 minutos com Eny Schuch, em Porto Alegre. Mais tarde, fizemos uma mini versão de 3 minutos que vou mostrar à vocês. As coisas vão surgindo meio por acaso. Quando fiz o vídeo pensei que algumas poderiam ser impressas. Imprimi para uma exposição em Bruxelas onde mostraria canetas Bic. Embora ninguém conhecesse este trabalho lá, eu queria mostrar algo novo e expus algumas sequências do vídeo em papel. Claro que fiz uma seleção. No vídeo havia mais de oitocentas imagens. Foi feito para uma catedral medieval que convidava à contemplação. Mas penso que ficar 78 minutos assistindo em uma exposição, poderia ser uma chatice. Então fizemos uma versão de 3 minutos para um festival, que está disponível no YouTube. Quando coloquei as imagens impressas na parede da exposição, percebi que o pessoal me perguntava com muito interesse. A partir daí, veio a ideia de fazer um livro, achei que seria a melhor forma de apresentar as sequências! O fato de mostrar é importante porque as pessoas te dizem coisas que podes nem ter pensado. Acho que um trabalho artístico deve 


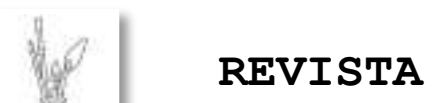 \\ (A) APOPHEKE}

ser mostrado para existir, para respirar, para que volte para ti e gere outras possibilidades. Essa troca é fundamental.

L.S.: Até que ponto a experiência do ateliê é importante para a ação de ensino?

T.P.: A experiência do ateliê é importante porque se compreende o processo de criação, suas angústias e dificuldades, embora não seja só isso que conte na vocação do professor. Às vezes o trabalho de ateliê é sofrido, angustiante, mas essa vivência permite entender e ajudar o processo dos alunos. E, às vezes, o aluno realimenta tua prática, é uma via de duas mãos. Com o grupo Atelier D43, esses meninos com quem trabalho, tenho uma relação de colega. Por vezes eles me dizem: 'Teresa isso eu não gosto', então procuramos entrar num acordo, é de troca mesmo. Muitas vezes mostro meu trabalho e pergunto o que estão achando. É bacana porque podem aportar coisas que me fazem pensar. São guris muito interessantes e inteligentes. Há alunos que têm capacidades que nós professores não temos, especialmente agora nessa questão de tecnologia. Esses meninos sabem muito, por exemplo, utilizar programas e redes sociais. Às vezes me falam: 'Tu não vês que nascemos com isto!', como quem diz, tu vais querer te meter nessa?! (risos).

Silvia Carvalho [S.C.]: Então já que o Leandro fez uma pergunta sobre ensino, vou dar continuidade. Você, que é professora de desenho e tem uma produção, em relação às suas experiências entre produzir Arte e Ensinar Arte, gostaria que falasse um pouquinho para nós sobre como e quando você se tornou professora. E como a prática de ensino teve impacto na sua produção artística no sentido de 


\section{H) Revrsta \\ A APOTHEKE}

você talvez ter menos tempo para produzir ou isso não mudou?

T.P.: Como é que me tornei... Na verdade sempre quis fazer Artes Plásticas. Vim de Bagé ainda criança para Porto Alegre e não me adaptava. Foi um horror, porque fui para um colégio alemão com uma disciplina rígida e uma cultura diferente, muito difícil. E gostava muito de desenhar, então minha mãe me colocou na Escolinha de Artes da UFRGS, onde trabalhei depois como professora, e ali decidi que queria ser artista. E anos depois, foi ali que decidi ser professora de Artes. A Escolinha foi importantíssima na minha vida. Isso de ser artista já tinha decidido desde criança, pois me criei naquele lugar que funcionava no Instituto de Artes, tu entendes? Olhava, através das janelas da Escolinha para a sala 43 onde dou aula até hoje e via os alunos do IA desenhando modelos, achava aquilo o máximo. Ainda muito jovem achava importante ter meu próprio dinheiro. Éramos criados num mundo muito diferente do de hoje e eu queria ser responsável por meu sustento para ter a liberdade e viver conforme minhas ideias. Comecei a dar aulas particulares de matemática para não precisar pedir dinheiro a meu pai. Enfim, essa era uma preocupação permanente, mas já havia o gosto por ensinar, e aulas particulares me deram isso. Adorava matemática e não gostava de ensinar 'decoreba', tipo memorizar uma fórmula, queria passar o prazer de pensar matematicamente, isso me estimulava. Os alunos me procuravam muito, as mães traziam outros filhos, principalmente para preparar para o vestibular. Isso me motivava. E nessa época, com 18 anos, fiz vestibular para Artes, como era meu desejo, mas logo fui morar no Rio de Janeiro para cursar engenharia postal. Foi um desvio maluco e ocasional destino que eu tinha escolhido. Fiz um concurso para incentivar meu irmão e 


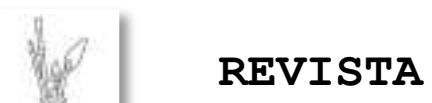 \\ A APOTHEKE}

acabei sendo aprovada graças à matemática. Enfim, acabei indo porque o curso oferecia uma bolsa vantajosa e eu queria, antes de tudo, ser independente. Mas, embora gostasse de cálculo e tal, odiei o tal no curso por causa dos estudos de administração. Em dois anos, voltei para o Instituto de Artes. Já tinha certa experiência como professora particular, mas achava que ser professora de colégio seria a pior coisa do mundo, via o quanto os professores sofriam nas nossas mãos quando éramos alunos. Mas a escolinha me fez mudar de ideia. Trabalhei anos lá como professora em condições ideais. Sabia que numa escola seria diferente, mas como não havia muita opção, fui trabalhar num colégio de freiras para testar e ganhar algum dinheiro. Era a aula da bagunça, muito difícil. Um dia cheguei no colégio e havia montinhos de argila que os alunos jogaram no teto e caíam na minha cabeça, um desastre. Eu pensava: Não vou conseguir! Mas continuei insistindo. As freiras disseram que eu não poderia ir vestida daquele jeito, de alpargata, saia comprida e aquelas coisas que a gente usava na época. Depois fui trabalhar no colégio João XXIII e, no início, também foi difícil. Às vezes eu chegava em casa chorando. Era complicado para uma jovem inexperiente tratar com adolescentes, mas encarava como um desafio e me dizia: Tenho que conseguir! Vou adotar outra estratégia! Continuei persistindo. Depois que consegues segurar uma turma de adolescente, tu podes dominar qualquer turma. O adolescente é realmente o grande teste. Aos poucos, comecei a curtir cada pequena vitória e a me apaixonar pelo trabalho. Agora, a outra questão. Tu perguntas como era ensinar e ao mesmo tempo ter o meu trabalho artístico, se não prejudicava no sentido do tempo. Claro, nesse sentido sim, sempre prejudicou. Produzia nos finais de semana, nas 


\section{Hervysta \\ A APOTHEKE}

férias, quando podia. Teve uma época que dava aula da manhã à noite. Sempre tendo uma produção pessoal, mas por necessidade mesmo, não tanto com a pretensão de ter uma carreira artística. Eu fazia exposições mais ou menos regulares quando achava que tinha algo que valia a pena ser mostrado. Tinha colegas com essa determinação, mas eu ia fazendo as coisas que surgiam e que gostava. Todas as experiências nessa área me interessavam. Depois, já com certa experiência, quando fui para Espanha, fiquei mais dedicada ao trabalho pessoal. Mas, foi só depois de ter feito Doutorado na França, quando tive que pedir licença da Universidade em Porto Alegre e voltar para lá, sem vínculo aqui, é que me dediquei realmente em tempo integral durante três anos ao trabalho como artista. Nesse período, senti pela primeira vez esse gosto. Ter tempo integral muda a maneira de pensar e trabalhar. Penso que isso me permitiu um salto grande na reflexão e na qualidade.

Havia marcado uma exposição na Bolsa de Arte quando fui viver em Eragny sur Epte. Embora esse lugar seja ao lado de Paris, fica na campanha e não é do meu feitio ficar parada vendo as estrelas. Queria ter um compromisso de trabalho garantido. Fiquei com medo do tédio, mas nunca aconteceu! Também pensei que iria sentir saudades de minhas aulas, mas não. Foi um período riquíssimo de produção, exposições e parcerias com artistas de lá. Depois voltei, é claro, mas foi difícil. E não porque não goste de ser professora, preciso das pessoas, por muito tempo me considerei mais professora do que artista. Sou uma professora mais de sala de aula mesmo, esta é minha praia. Não viajo muito à trabalho, não quis ir para a Pós-Graduação. Procuro fazer o melhor que posso na Graduação, que deve ser fortalecida com pesquisas sérias e aulas interessantes. Procuro fazer isso; 


\section{$x$ \\ REVISTA \\ APOTHEKE}

escrever e fazer exposições sozinha ou com alunos, sempre que acho que vale a pena.

Enfim, nessa época, foi difícil de abdicar desse tempo integral e recomeçar como professora.

S.C.: Dessa forma, você consegue lidar com seu processo artístico?

T.P.: É. Mas menos do que se eu tivesse mais tempo, é claro. Já estou com 60 anos e, se eu tivesse pensado que um dia iria envelhecer, sim porque envelhecer e morrer eram abstrações, se tivesse descontado para aposentadoria, já teria mais do que tempo para me dedicar somente ao trabalho pessoal agora. Mas, se não fiz, talvez seja porque, no fundo, queira continuar trabalhando com ensino, sei lá. Sou muito obcecada por trabalho, descanso trabalhando. (risos)

S.C.: Como você pensa o ensino de Arte na Instituição de Ensino Superior?

T.P.: Pois é. Tu sabes, a gente estava comentando isso aqui, né? (Ateliês da UDESC) Um espaço maravilhoso e ninguém. Realmente, não vi nenhuma pessoa trabalhando aqui a não ser aquela menina ali embaixo, na cerâmica. Não tem o que te dizer. No Instituto de Artes não é tanto assim. Aqui, fiquei mais espantada porque a estrutura é muito melhor e o número de alunos trabalhando, muito menor, um deserto. Mas lá também temos alguns ateliês com muito menos gente trabalhando do que gostaríamos. Penso que muitas vezes os alunos não tomam posse dos seus próprios espaços públicos, do que pertencem a eles. Isso não é só no Brasil. o que acontece no Brasil é que os alunos chegam à Universidade muito desinformados, vocês sabem que nosso Ensino Básico é fraco, e chegam sem a menor noção de História da Arte. Sabem mais ou menos quem foi Picasso e olhe lá... sabem que Van Gogh cortou a orelha. Em geral, é 


\section{H) Revrsta \\ (A) APOAнEKE}

só. E já começam na Universidade com uma informação de ponta, trabalhando com filósofos contemporâneos, lendo Bordieu, quando não sabem quem foi Platão. Posso estar enganada, mas me parece que não existe uma História da Arte linear que permita uma relação de causa e efeito, não se fala mais nisso. A própria palavra 'didático' se tornou uma coisa feia, como se fosse burro ser didático. Acho isso pretensioso e fora da nossa realidade. Exposições públicas devem ser para que as pessoas entendam. Tu podes ser didático e não subestimar a inteligência do público, mas fazer uma coisa que instrua também. Acho que isso é honestidade intelectual. Então, muitas vezes, isso afasta o aluno da Universidade no sentido mais genuíno. O ambiente acadêmico às vezes propicia isso, em outros países também. Precisamos de mais humildade intelectual, desculpe, a palavra acho que não é essa, mas de um certo realismo. Precisamos entender que esse aluno que entra na faculdade, é como é e não como gostaríamos que fosse. A meu ver, seria importante que no primeiro e no segundo ano pudesse ter uma base de História da Arte e de Desenho de forma mais linear. Não adianta começar com Arte Conceitual sem ferramentas básicas importantes. É em geral complicado para um aluno desinformado entender Arte Contemporânea. A fusão das linguagens na música, na literatura, não é tão manifesta, mas as Artes Visuais se tornaram um balaio de gato onde cabe tudo e tudo é possível. É claro que essa liberdade é bem-vinda e que o aluno precisa ser inserido na contemporaneidade. Mas precisaria conhecer e compreender certas relações introdutórias. Senão, que liberdade terá para poder analisar, criticar, escolher?

É importante vocês chamarem também professores aqui, como no caso Frantz, que não são acadêmicos, isso eu já acho uma abertura que não acontece muito e é muito bacana. 


\section{1) Revyssa \\ (4) APOTHEKE}

Jociele Lampert [J.L.]: Aqui isso também não acontece, a gente faz acontecer, a gente força.

T.P.: Isso é muito legal.

J.L.: Mas esse é o nosso papel também.

T.P.: É claro. Tens razão Joci, se a gente não fizer isso quem é que vai fazer? Com o Ateliê D43, o grupo que é parte de minha pesquisa 'Desenho, Gesto e Pensamento: procedimentos gráficos e outras mídias' e trabalha o desenho e seus cruzamentos, misturas de um desenho contaminado por outras linguagens, a gente faz círculos de conversa com artistas. Chamei artistas amigos que vinham no amor, sem ser pagos nem nada. Vinham fazer um bate papo, sem microfone, na sala 43, a sala de desenho que deu nome ao grupo. E todos os artistas convidados são de fora da Universidade. Chamamos pessoas para falar de assuntos que têm a ver com a essa pesquisa. Jorge Furtado, cineasta, por exemplo, foi falar sobre história em quadrinhos, desenho e cinema, Mauro Fuke foi falar sobre desenho como projeto, designer. Cada um pensando desenho num aspecto a ver com o trabalho do grupo. Mas a gente não chamou ninguém da Universidade justamente para abrir. Na nossa exposição, 'Lugares do desenho', tampouco chamamos professores da Universidade. Quando realizei a exposição 'Porto Alegre em foco', com Eny Schuch, com 478 participantes do mundo inteiro na Pinacoteca do IA em 2004, da mesma forma. Sempre procuro sair um pouco do âmbito acadêmico, senão fica a coisa fechada no nós para nós mesmos, não é?! Na França, tenho uma amiga que diz que na Universidade se auto reproduzem. O estudante sai da Graduação e vai fazer a Pós e a Pós da Pós. Frequentemente, vira professor e quando faz exposição é, muitas vezes, dentro de um circuito acadêmico. 


\section{(4)}

Esse círculo vicioso que acontece em todas as profissões. Mas justamente o conceito de Universidade, no sentido genuíno, é também abrir para a comunidade, o universal.

\section{Segundo momento:}

S.C.: Eu tenho o questionário do Joe Fig, podemos?

T.P.: Pode ser.

S.C.: 1. Quando foi que você se considerou uma artista profissional e quando se sentiu capaz de se dedicar em tempo integral à Arte?

T.P.: Never (risos). Não consegui ainda, em certo sentido estou louca para me aposentar e conseguir. Quando me considerei profissional, não sei. Nem sei muito bem o que é ser profissional. Quando fazia Matemática e Artes, quase me formei em Matemática, mas chegou um momento em que tive de optar. Lembro que, nesse período, o primeiro trabalho que vendi numa exposição em 79, foi para Dona Alice Soares, que era minha professora. Ela me dava muita força e talvez tenha comprado só para me incentivar. Eu adorava a maneira como ela ensinava, não tanto o trabalho dela, mas as coisas que falava como professora, isso também foi muito importante para me tornar artista e professora. Quando dizem para fazer um currículo, onde é que começa um currículo? Desenhar sempre desenhei, todo mundo desenha. Considero que comecei a me profissionalizar quando comecei a expor. Mas posso dizer que, apesar de tantos anos de trabalho, faz muito pouco tempo que comecei a achar que realmente meu desenho tinha alguma coisa mais genuína a dizer, foi quando estava na França. Foi aí que comecei a me achar capaz de aportar alguma novidade, tanto no plano prático como teórico. Bem recentemente. Claro, em várias ocasiões as pessoas elogiam e tal, mas sempre relativizo e fico pensando que, quem não gosta, não fala. Então só 


\section{(7) Ryysta \\ A APOTHEKE}

recebes os elogios quando seria importante receberes também críticas, que raramente vem. Quando se ouve: 'Nessa exposição, só recebi elogios'... é normal, só se recebe elogios mesmo e isso, em si, não quer dizer muito. Mas tem alguns elogios que fazem com que a gente se acredite, 'Que a gente se jure' como diz um sobrinho meu. Lá na França, recentemente, aconteceu isso com algumas pessoas cuja crítica e opinião foram importantes para mim.

S.C.: 2. E, então, quanto tempo tem estado em estúdio?

T.P.: Ah, pois é. Por exemplo, agora que estou para fazer essa exposição, eu ficava trabalhando todo o tempo que eu não estava dando aula. Ficava obsecada, sem sair, dormindo pouco e sem descanso. É de manhã, de tarde, de noite, domingo, sábado. A casa estava vazia, eu a invadi e fiquei trabalhando full time. Em geral, sempre fico, mas quando tenho um compromisso assim não posso fazer mais nada, porque imagina preparar, fazer tudo isso em cinco meses. Agora, por exemplo, tenho um projeto, um trabalho que vou fazer com o Vagner Cunha, que é um disco e um DVD. Mas não sei para quando vamos conseguir, pois tanto ele quanto eu somos muito ocupados. Em geral, sempre que saio de um trabalho já tenho outros. Se não tenho, invento, já me acostumei a viver assim e preciso disso. Normalmente, são muitas coisas ao mesmo tempo, mas as aula são prioridade e uma atividade contínua. Quando se faz o que se gosta é uma benção na vida, a maior delas. As pessoas mais próximas reclamam que estou sempre trabalhando, que preciso me interessar por outras coisas! (risos). Aí tenho medo de virar aquela esquisita, que ninguém aguenta (risos), obsessivo total, insuportável. Fazer o quê?!

S.C.: 3. Quando você começou a trabalhar neste espaço? 


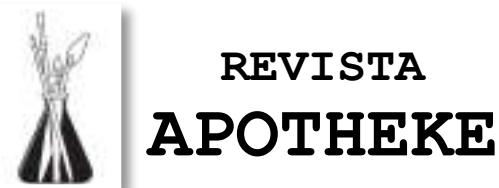

T.P.: Voltei da França em 2009, e em 2010 fui para este ateliê. Não é tão grande, mas tem um terraço com uma vista muito linda. Dos locais que tive para trabalhar, em Porto Alegre, este é o melhor. É uma cobertura de dois andares e em cima fica o ateliê.

S.C.: 4. A localização de seu estúdio influenciou seu trabalho de alguma forma?

T.P.: Eu já tive vários estúdios, que chamo de ateliê, em locais diferentes, mas em geral onde moro, nunca gostei de me deslocar, perderia muito tempo. Se estou em casa, posso trabalhar até três horas da manhã, dormir e voltar a trabalhar. Se morasse longe, dependeria de táxi porque não dirijo e, para mim, facilita muito. Quando eu morava em apartamentos menores, fazia um tanque e um ateliê, deixando o quarto menor como quarto. Era mais ateliê do que casa. Lá na França era assim também, por quatro anos em Paris. Morava em uma zona mais nova, em um prédio bem alto na Place d' Italie, onde se via através de uma janelinha aquelas ogivas do Panthénon e a Torre Eiffel, tipo cartão postal. Aquele monte de janela e de grades, mesmo sem querer, acabam influenciando o trabalho. No ateliê que pertenceu a Pissarro, que era pertinho de casa, não podia trabalhar de noite nem no inverno, pois não tinha luz ou aquecimento. Desenhava num cenário de natureza e isso ia integrando o trabalho sem que, muitas vezes, eu me dessa conta.

S.C.: 5. Você pode descrever um dia típico em sua vida?

T.P.: Eu gosto da rotina. Porque minha vida já teve coisas nada banais e muito difíceis. Fico contente de voltar provisoriamente ao cotidiano depois de uma exposição muito movimentada. Sempre me entrego demais nessas coisas, não 


\section{1) Revyssa \\ (A) APOAHEKE}

sei ser diferente. Mas gosto de ficar menos acelerada, ver um filmezinho. Antigamente eu talvez não gostasse, mas agora gosto da rotina, embora mantê-la me seja difícil. Sempre tem coisas inesperadas, vernissage de um aluno que tens que ir, de outro que escreveste o texto. Faz parte da minha vida e gosto, mas depois de tantos anos, muitas vezes prefiro ficar trabalhando com minhas coisas. Sou uma pessoa falante, gosto de encontrar os amigos, mas tenho necessidade também de silêncio. Se me disseres: 'Vais ter dez dias sem falar com ninguém, só trabalhando', acho ótimo. Consigo fazer isso com prazer, sabe. Porque o melhor é fazer o que se gosta e nesses momentos não me sinto sozinha. Quando chega a hora de mostrar numa exposição é importante e necessário, é isso que dá sentido ao trabalho. Mas o melhor mesmo é fazer, quando surge algo e se tem a felicidade solitária de um momento raro que apaga a angústia e a fatiga. É muito intenso e especiúfico. o prazer de gerar uma coisa é diferente do prazer de ler um livro ou ver um bom filme. Enfim, uma experiência intransferível como todas as experiências intensas. Assim como a angústia que acompanha a criação. Sempre acho que não vai sair mais nada de novo, que já fiz o que podia fazer. Mas uma coisa vai puxando a outra e o trabalho mesmo vai abrindo caminho. Porque é engraçado isso, ele se auto gera, como se fosse uma coisa meio mediúnica (risos), mesmo que a gente não force nada.

S.C.: 6. Você costuma ouvir música, rádio, TV quando está trabalhando, e isso afeta seu trabalho?

T.P.: Quando estou trabalhando ou fazendo um texto não gosto de ouvir nada. Mas quando estou desenhando, dependendo do trabalho, às vezes consigo ouvir música sim, e às vezes até rádio. Foi o que aconteceu na fase mais 


\section{ע)}

manual daqueles desenhos que vocês viram com canetinha Bic, um trabalho muito miudinho que tenho que colocar na vertical para ver e só depois executar na mesa. Era como um bordar sobre papel. Um bordado que durava muito tempo e que requer mais paciência do que tudo que costumo fazer.

Gosto de ouvir música e de ver filmes na TV, comecei com esse hábito morando no campo onde não tinha muito como ir ao cinema, mas de me concentrar no que estou escutando. Poder ver um filme em casa, aqui nós temos essa possibilidade de gravar quando tem um filme de Arte ou um programa novo. Vejo o jornal, essa rotina eu gosto. Às vezes, dou uma parada para ouvir uma música. E gosto de ler também. Quando jovem lia mais poesia, mas agora é mais romance. Agora me apaixonei por aquele português o Valter Hugo Mãe, muito bom. Aí pego vários dele. Às vezes leio livros de Arte, mas não de forma tão sistemática como fiz durante muitos anos. Voltei para os romances, que adoro, embora leia menos e mais devagar do que gostaria.

s.C.: 7. Que tipos de tinta você usa, que tipos de materiais você usa?

T.P.: Sempre gostei muito de usar materiais não tão comumente utilizados por artistas, alguns que normalmente crianças usam, como lápis de cor ou grafite e materiais banais, mas uso materiais de boa qualidade. Tento tirar o máximo proveito desses utensílios simples como a canetinha Bic, que emprego por ser o instrumento da escritura e mostrar o gesto pequeno da mão. Consultei vários profissionais e sobre a duração da caneta Bic com a ação da luz. Qualquer material que sofre ação do sol e da luz vai esmaecer. Mas, na caneta esferográfica, isso é pior por causa do chumbo. Quando se coloca o vidro, já filtra bastante. Existem vidros para Museus que tem filtro UV, mas 


\section{W| Revrsta \\ A APOTHEKE}

são tão caros que só se justifica num Van Gogh, por exemplo. A solução é se aplicar no vidro molhado uma película do tipo que se coloca nos carros que, em vez de fumês, existe também transparente. Tem que saber colocar mas é um bom filtro, não só para a caneta Bic, mas para proteger outro tipo de material.

S.C.: 8. Fale-me um pouco sobre suas paletas de pintura.

T.P.: Comecei com o que considero pintura, na Espanha, com um pintor influenciado pela Escola de Nova Iorque, um espanhol que adoro, Carlos León. Seu trabalho ainda me fascina, fazia coisas imensas. A gente trabalhava numa nave imensa e instalava as coisas no chão. Não trabalhávamos com tinta pronta. Lá em Madri, tinha uma loja antiquíssima, só de pigmentos, que vende a granel, sabe. Vão colocando meio quilo de amarelo cádmio em saquinho de papel pardo, uma maravilha. E neste ateliê, cada um tinha um espaço grande e fabricava as suas tintas misturando pigmentos e aglutinantes. Mas ultimamente, com desenho, utilizo materiais prontos que compro na França e trago. O que faço não é mais pintura, embora tenha a ver com pintura no sentido de que não há mais contorno, a linha cria texturas. Não existe, como na forma fechada pelo contorno, uma relação de figura fundo. São campos de tonalidades. Quando optei por fazer essa exposição, pensei: Vou fazer só com 3 cores, tudo foi decidido antes. Aqui serão quadrados, nessa parede terá um vertical para quebrar o ritmo. Ali deverá ir o vídeo. Pensei em trabalhar com cores frias, que tinham a ver com caneta Bic, sobretudo para compensar um gesto que é forte, emocional. Essa compensação é necessária para estabelecer a tensão. Se trabalhas com cores muito quentes e energia forte, estás dizendo duas vezes a mesma coisa. Precisamos de contrapontos. A primeira vez que vi a Guernica na Espanha, uma das coisas que me impressionou 


\section{H) Revrsta \\ A APOTHEKE}

foram as cores frias; isso não tirava sua força dramática, mas ao contrário, a tornava mais potente. Se as cores fossem quentes, poderia haver um efeito redundante como um ator exagerado que não convence. Uma emoção contida adquire mais força. Senti algo parecido com as cores frias de uma pintura de Joan Michell, no Museu de Grennoble. Ela pintava de um jeito explosivo, meio Cy Twombly. Sempre achei que era uma versão contemporânea de Monet, vizinho e compadre de Pissarro, depois descobri que a artista canadense morava pertinho de Eragny e de Giverny. Queria fazer uma grande instalação, aproveitando a arquitetura da galeria, que mostrasse esses gestos quentes com cores frias, por isso optei por verdes e azuis. Um trabalho mais colorido tem um apelo de sedução imediato, acredito que as pessoas gostem mais, mas não era o que eu queria. Dentro da História da Arte, sempre teve aquela pendenga entre a cor e a linha, o desenho e a pintura, de a cor ser um ornamento etc... o Duchamp falou justamente dessa arte retiniana etc... que valorizava mais a coisa do olho, que era o que os impressionistas faziam. Na verdade, o Duchamp nunca imaginou que ele seria o Duchamp, que teria essa importância toda. Talvez muitas coisas que se falam sobre ele sejam até viagem. Acho interessante pensar que quando ele fez aquele ato inaugural do ready-made, não foi o único responsável, quem permitiu que o objeto fosse exposto foi tão revolucionário quanto ele. São os atores esquecidos da História. Mas isso é outro assunto.

S.C.: 9. Existem objetos específicos (no ateliê) que têm um significado importante para você?

T.P.: Não sei se um significado, mas uma importância prática também. Gosto de ter os livros todos no ateliê. Hoje, por exemplo, trabalho muito com computador, e tenho 


\section{Hervysta \\ A APOTHEKE}

que ter quase um estúdio de fotografia, tripés, máquinas, iluminação. As coisas têm que ser bem fotografadas. Tive que investir nisso. E também em projetor e material para vídeo. Mas, meus lápis continuam nas mesas e as paredes forradas de tábuas para eu poder fixar os trabalhos. Quase nunca trabalho na horizontal. A não ser com caneta Bic que precisava de uma mesa bem grande e colocava na parede apenas para poder enxergar o trabalho. O ateliê tem de ser uma coisa muda em função do trabalho, as mesas se desfazem sobre cavaletes. Quando trabalho na vertical, muitas vezes uso escada para fazer coisas mais altas. Esses aqui, quando estavam no ateliê, precisava fazer de dez em dez e ia numerando como se fosse uma matriz. Tinha que ficar em uma escada ou banquinho para trabalhar. É um trabalho físico que não sei até quando poderei fazer. Por causa do desenho, tenho há anos problemas de bursite. As vezes dá muita dor. Por exemplo, quando trabalhas com a ponta seca, tem que vir com muita força. Mas, a gente vai levando, sempre tem um dorzinha ou outra. Faz parte da vida, vai fazer o quê? Vai parar por causa disso? Tem amigos que dizem: 'Tens 60 anos, faz coisas pequenas'. Mas, enquanto der, vou trabalhando.

S.C.: 10. Você tem ferramentas que são exclusivas para o seu processo criativo?

T.P.: Depende do que estou fazendo, agora por exemplo, uma das ferramentas é o computador, máquina fotográfica, nesse momento é isso. Por exemplo, eu preciso mandar imprimir, preciso usar o Photoshop, usar determinados programas e depois o lápis, o papel. Não desenho com o mouse, uso o lápis e papel, mas tenho essas ferramentas e também experimento efeitos com elas. Tem esses trabalhos de $1,60 \times 1,60 \mathrm{~cm}$, tudo o que é preto foi impresso. O desenho em lápis de cor vem em cima do que foi impresso e antes era 


\section{Hervysta \\ A APOTHEKE}

gravura. Os verdes e azuis são desenhos. Aqui, por exemplo, eu fui com lápis de cor e usei também muita água, fui lavando até que resolvi. Ali, já é um outro processo, são os trabalhos que estou fazendo, grandes. Essa é a primeira parte, só preto e branco. Nesse aqui, passo pigmento, azul da Prússia, é muito volátil e começou a entrar no nariz, é chumbo, não dá. Comprei uma máscara e trabalho assim, tipo astronauta, de máscara e óculos, com umas roupas terríveis, uma coisa engraçada e incômoda. Machuca o nariz, dá coceira, tem de tirar aquela máscara, é muito chato, mas é o único jeito. São cuidados mínimos. Esses aqui compridos, refiz porque o branco não ficou bem branco, o ruim é que é caro imprimir nessas dimensões. Trabalhei também com alguns grandes marrons. Olhem para essa cópia e para essa, ficaram bem diferentes, são de uma gravura pequena. Aqui é o que vocês viram na caixa da Joci, já é outra coisa, são fotos e desenhos justapostos. Só que aqui, é uma gravura, uma gravura sobreposta a uma foto, misturando as imagens e criando uma terceira. Como pediram um trabalho para uma exposição de fotografia e eu não queria mostrar o que já mostrei, surgiram essas imagens sobrepondo outras que tinha guardado. Já tinha pensado em fazer isso. Os frames no vídeo que geraram essas imagens da caixa vão entrando um no outro e pensei: porque eu não faço isso na impressão? A ideia já existia, só faltava a oportunidade para botar em prática. As coisas vão se desencadeando.

S.C.: 11. Você trabalha em um desenho de cada vez ou em vários ao mesmo tempo?

T.P.: Depende do espaço que disponho. Tive a oportunidade incrível de trabalhar no antigo ateliê do Pissaro. O local ficou cem anos deserto, sem ninguém entrar para trabalhar desde sua morte em 1903. A proprietária do local, que 


\section{(7) Ryysta \\ A APOTHEKE}

conheço há muitos anos, me abriu as portas do ateliê. Fiquei lá durante muito tempo, não imaginas. Ali fizemos inclusive dois filmes, um feito por mim, sobre a experiência a quatro mãos com a artista chinesa Dai zheng, quando terminei minha Tese de Doutorado em Paris. Levamos um monte de coisas, tinta e tudo, fizemos uma super faxina, porque estava um horror. O vídeo se chama 'Três dias a quatro mãos no ateliê Pissaro' e foi mostrado em uma exposição com o mesmo título feita em Gisors, uma cidade próxima, para comemoração dos cem anos da morte de Pissarro, e em Paris. Anos depois, em 2009, trabalhando sozinha lá, convidei dois artistas franceses que ficaram uma semana repartindo o ateliê comigo. O cineasta Sylvain Palfroy, que havia feito um filme sobre Pissarro, ficou uma semana filmando nosso trabalho e realizou um filme chamado 'Três pincéis e uma conversa' (em tradução aproximada). Esse filme é maior e com maiores recursos. Mas voltando à tua pergunta, quando trabalhava sozinha nesse ateliê, fazia vários trabalhos ao mesmo tempo, porque o espaço era enorme, quadrado, e eu podia colocar muitas folhas de $1,50 \times 1,50 \mathrm{~cm}$ ou mais. Aproveitava a altura máxima dos rolos. Aqui, faço $1,62 \times 1,62 \mathrm{~cm}$, a altura máxima para imprimir. Gosto do formato quadrado, é mais neutro, nem paisagem, nem retrato. Então, ia trabalhando ao mesmo tempo um monte de desenhos. Como estavam todos ali, ia resolvendo tudo junto, acrescentando as camadas. Podia comparar e estabelecer a relação entre eles, ver aqueles que não estavam bem resolvidos em relação aos outros, tinha recuo. Em casa não tenho essas condições, coloco dois grandes, não mais do que isso.

Nessa época, eu trabalhava religiosamente durante todo o dia. Acordava de manhã cedo, fazia ginástica, ia para lá trabalhar, super metódica. Trabalhei muito nessa época, de 


\section{(A)}

chegar em casa e ter aquela sensação boa de um cansaço físico.

S.C.: 12. Quantas vezes você limpa o seu estúdio, e qual o efeito disso sobre seu trabalho?

T.P.: Eu limpo pouco, eu sou meio bagunçada. Mas, em geral quando vou recomeçar a trabalhar, preciso dar uma limpada. Agora, tenho muita dificuldade para me organizar, botar fora as coisas. No meu computador se vocês tivessem a noção da quantidade de imagem... aí eu compro outro HD e vou botando no outro, e já não sei mais se está nesse ou no outro, é uma confusão. Mas como é que eu vou fazer para organizar a quantidade de imagens tenho? Vou ficar anos organizando e deixar de fazer coisas mais interessantes. Deixa assim, vou morrer antes (risos). Vou colocando dentro dos HDs e pronto. O computador é o mais difícil de organizar, se não te organizas desde o início, é complicado. Então, quando não acho um arquivo, procuro e acabo encontrando mesmo que demore mais.

S.C.: 13. Quando você está pensando em seu trabalho onde você costuma sentar ou ficar?

T.P.: Quando estou muito dentro da coisa vou dormir pensando, louca para acordar e resolver. Como um desenho, um texto, deixo dormir, no outro dia, vou lá e olho. Às vezes tu olhas e parece que está bem, mas no outro dia não está. Muitas vezes, peço opinião para alguém. Depende do trabalho. Essa montagem, resolvo no computador, é onde penso a composição, é mais cerebral. E penso meus trabalhos sempre em função do local. Nunca fiz uma individual sem conhecer o espaço. Se precisar, viajo. Me dá nervoso fazer uma exposição em um lugar que não conheço. Quando fiz uma exposição em Bruxelas, fui lá conhecer e pensar o que 


\section{H) Revrsta \\ A APOTHEKE}

colocar naquele espaço. Não consigo só por fotos, não dá. Quando é coletiva, esse problema é de quem organiza. Quando fiz aqui, já sabia exatamente onde cada coisa iria, quando fomos montar foi fácil. Claro que mesmo que saibas, que tenhas na tua cabeça e no papel, às vezes quando estás dentro do espaço, tudo muda e tens que mudar. Mas preciso ter um plano para me sentir segura. Ao mesmo tempo que sou desorganizada para algumas coisas, sou tri obsessiva para outras. Na exposição individual deste Territórios da folha, que o Eduardo Veras fez a curadoria, fizemos uma super organização, pois a mostra tinha um cunho retrospectivo. Tínhamos que garimpar onde estavam alguns trabalhos etc. No espaço menor, Eduardo queria trabalhos pequenos e vídeos. Fiz até uma maquete onde íamos colocando os quadradinhos impressos em escala. Sabíamos onde colocar, se não iriam ficar malucos, pois eram muitos trabalhos. Imagina não saber onde vai ser o quê?! Em geral, eles têm pouco tempo para montar e muitos problemas técnicos a resolver. Havia poucos recursos, mas trabalhamos realmente em parceria e tudo deu certo. Eduardo foi um super curador. Eu, que sempre concebia as exposições sozinha, adorei trabalhar com ele e a equipe do Museu.

S.C.: 14. Como é que você escolhe/cria os seus títulos?

T.P.: Ah, eu não tenho como pensar títulos para cada desenho, por isso intitulo-os por séries. Este vídeo, por exemplo, ia chamar Outono, o Vagner, que tinha feito a música pensou numa série de prelúdios, depois pensei que Outubro tem um nome parecido e traz essa sazonalidade do outono, achei um mês mais bonito que uma estação. Agora, para uma exposição eu penso muito num nome. Alguns eu tenho na manga para usar um dia. Para essa, eu não achava um nome, tinha pensado em combinações, procurava, perguntava 


\section{Hervysta \\ 4) APOHHEKE}

para os amigos, fazia enquete. Acho que através de pesquisas na internet, veio essa palavra Anagramas que caiu como uma luva, pronto, achei na hora. A outra, Territórios da folha - paisagens de Teresa Poester, demorou. Pensei em Fronteiras da paisagem, que era título da minha tese, porque não me vinha outra cois. Eduardo queria que aparecesse o nome paisagem que era a costura da coisa. Aí chegou o poema de uma amiga, que tinha essa frase. Aquela, não sei quantos quilômetros em linha, também veio assim. Estava pesquisando a duração de uma esferográfica e encontrei a distância percorrida pela caneta Bic. Comecei a pensar nos quilômetros de linha que já devia ter percorrido com meus desenhos. Às vezes são outras pessoas que dão o título.

S.C.: 15. Você tem assistentes?

T.P.: Às vezes tenho para coisas específicas. Tem uma amiga que me ajuda em trabalhos que comercializo na loja da Fundação Iberê, se encarrega dessa parte. Às vezes, quando estou trabalhando com vídeo, chamo alguém que me ajude naquele trabalho específico. Felizmente, sempre tenho alguns alunos ou ex-alunos muito bons para determinadas situações. Quando fiz o mural grande para a praça de um Centro Cultural em Bagé, tive uma assistente que trabalhou com cerâmica comigo, que botava no forno, tirava do forno, essa parte técnica. Era excelente essa moça. Então pego assistentes para certas demandas. Às vezes vejo esses guris de trinta anos, todos com assistentes, e penso: 'Ah, eu devia ter uma assistente' (risos). Tenho uma amiga que diz: 'Teresa, você é uma artista, devia ter várias assistentes, devia ter um séquito de assistentes', mas sou desorganizada e, do jeito que eu sou, chega assistente lá e eu digo: 'Então tá, hoje eu estou noutra'. Para o assistente vai ser 


\section{Herysta \\ A APOTHEKE}

um problema (risos). Porque para dar trabalho, vou ter que me organizar, e não sei se vai dar muito certo. Eu faço muita coisa e preciso mesmo, mas vou levando assim com estes ajudantes. Um assistente só teria de saber muitas coisas diferentes, mexer em site, mexer em vídeo, ser bom nessa parte de organização e é difícil de encontrar tudo num só.

S.C.: 16. Alguma vez você trabalhou para outro artista?

T.P.: Eu trabalhei com outros artistas, não para outros artistas, a não ser fazendo cenários para teatro e cinema, mas foi uma experiência curta. Lá na França, por exemplo, trabalhei em parceria com vários artistas, como a pintora chinesa ou o pianista de quem falei antes, e também com Marianne Chanel e Françoise Valléé, que fez comigo várias exposições e trabalhos a quatro mãos.

S.C.: 17. Como artista, você tem algum lema ou credo?

T.P.: Não, ou talvez sim, porque acredito que a Arte pode fazer as pessoas viverem melhor e não poderia me imaginar fazendo outra coisa. Sei que isso me segurou em momentos muito difíceis e que, sem isso, não sei se teria conseguido prosseguir. Provavelmente, esteja sendo ingênua, mas como artista ou como professora, se pudesse contribuir para que algumas pessoas acreditassem mais na vida e em si mesmas, já seria muito bom. Existe uma ética na Arte, uma ética de liberdade, e acho que isso é o mais importante, porque o resto passa e é rápido. A liberdade de criar é uma coisa pela qual se tem de lutar todos os dias. Tampouco se pode depender de as pessoas gostarem do trabalho, tu dás aula, daqui a pouco estás expondo numa galeria, na rua com teus alunos, daqui a pouco estarás fazendo um mural que não tem nada a ver com isso. Se ficas só em uma coisa, acabas 


\section{\)}

dependendo demais daquilo e sofres se aquilo não funciona. É importante abrirmos frentes. É bom saber pintar, saber fazer vídeo, saber montar um cartaz, sem depender do artista gráfico, do diagramador, te dá mobilidade, liberdade. E essas atividades todas se somam, pois tudo isso faz parte da criação.

S.C.: 18. Qual conselho você daria a um jovem artista que está começando?

T.P.: Tenha curiosidade. E trabalhe muito. Não vai vir algo de fora, do outro. Tenha persistência. Porque o que eu vejo menos por aí é o pessoal tendo curiosidade e persistência. Acho que isso talvez tenha mudado com essa coisa de internet, com a facilidade que se tem hoje em fazer pesquisa. Nós vivemos em um mundo de informação e de excesso, isso não incentiva as pessoas a buscarem. Saber querer, ter vontade. Parece que as pessoas ficaram meio blasé, que tudo já vem pronto e já foi visto, e não é assim. A curiosidade é fundamental. Então, acho que o papel do professor não é tanto dar informação, mas proporcionar reflexão mesmo, que não vem assim com um clic no computador.

1 Extrato de entrevista com a Artista Professora Teresa Poester realizada por Silvia Carvalho, Leandro Serpa e Jociele Lampert, no Ateliê de Pintura do Departamento de Artes Visuais da Universidade do Estado de Santa Catarina, em Florianópolis, no dia 08 de setembro de 2015, na aula aberta promovida pelo Grupo de Estudos Estúdio de Pintura Apotheke. Parte da entrevista teve como referência o questionário presente no livro de Joe Fig, Inside The Painter's Studio(Princeton Architectural Press, 2009). 


\section{X) Revyssra \\ A APOTHEKE}
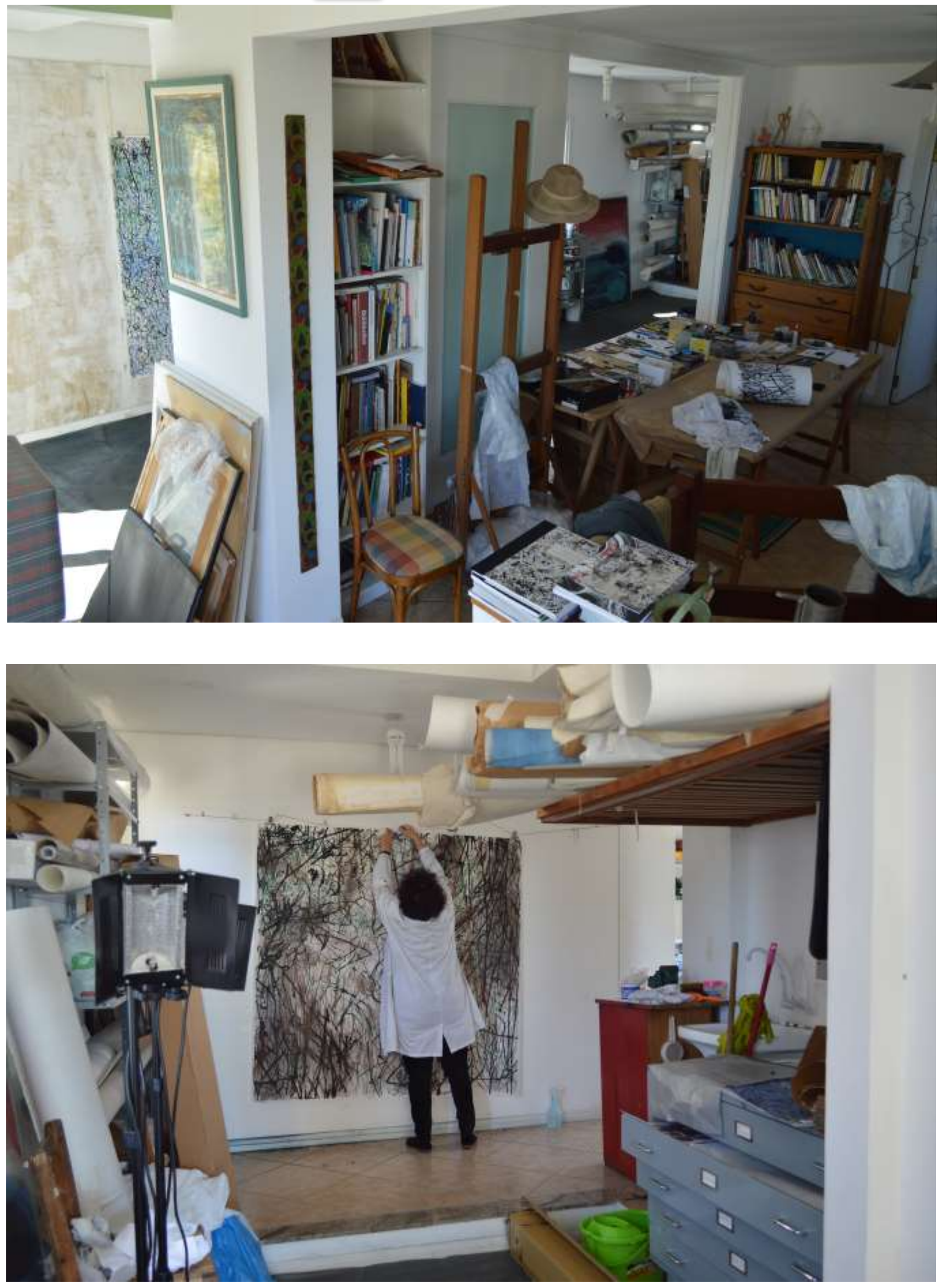